\title{
Micronucleus Frequencies and DNA Repair Gene XRCC3 Polymorphism in Radiation Workers of Center for Multipurpose Reactor
}

\author{
D. Ramadhani ${ }^{1}{ }^{1}{ }^{*}$, Y. Lusiyanti ${ }^{1}$, M. Syaifudin ${ }^{1}$ and S.M.H Faradz ${ }^{2}$ \\ ${ }^{1}$ Center for Radiation Safety Technology and Metrology, National Nuclear Energy Agency, \\ Jl. Lebak Bulus Raya No. 49, Jakarta 12440, Indonesia \\ ${ }^{2}$ Center for Biomedical Research (CEBIOR), Central Laboratory of National Diponegoro Hospital, \\ Jl. Prof. H. Soedarto, SH, Tembalang, Semarang, Indonesia
}

\section{ARTICLE INFO}

Article history:

Received 27 September 2016

Received in revised form 14 January 2018

Accepted 29 January 2018

\section{Keywords:}

DNA repair

Micronucleus

Polymorphism

Low dose radiation

Radiation workers

\begin{abstract}
A B S T R A C T
The carcinogenic effects of low radiation doses have not been fully understood until now. Studies on individuals that are occupationally exposed to low radiation doses can help to address this question. This study assesses the micronucleus (MN) frequencies as indicator of DNA damage in radiation workers that are occupationally exposed to low radiation dose. The influence of single nucleotide polymorphisms (SNPs) in XRCC3 gene on the frequency of micronuclei was also evaluated in this study. The effects of confounding factors of gender, age, and smoking status on MN frequencies was assessed in all samples. A total of 60 subjects consisting of 30 radiation workers from Center of Multipurpose Reactor (CMPR), National Nuclear Energy Agency (NNEA) of Indonesia, and 30 control samples were enrolled in this study. The results showed that the difference between MN frequency in radiation workers and in control samples was not statistically significant $[0.019$ vs. $0.021 ; p=0.549]$. Age and smoking status did not affect micronucleus frequencies in all samples $(p=0.723$ and 0.828). Micronucleus frequencies in females were higher compared to males, even though the difference was not significant $(p=0.3)$. Radiation workers with variant alleles for XRCC3 polymorphism did not showed higher $\mathrm{MN}$ frequencies compared to the controls with the same genotypes. The small numbers of samples with XRCC3 variant alleles found in this study possibly contributed to the insignificant difference of MN frequencies between wild-type allele $(T h r / T h r)$ and mutant alleles (Thr/Met or Met/Met). Further investigations using larger sample sizes and $\mathrm{MN}$ assay in combination with human pan-centromeric probe should be conducted to validate this study results. Other SNP in XRCC3 gene also should be evaluated to find out the association between $\mathrm{SNP}$ and $\mathrm{MN}$ frequencies.
\end{abstract}

(C) 2018 Atom Indonesia. All rights reserved

\section{INTRODUCTION}

Radiation workers receive occupational exposure to ionizing radiation in their works. The irradiation exposure of this group is mainly external, and comes mainly from $\gamma$-radiation, with a negligible exposure to $\beta$-radiation and neutrons. The occupational exposure is a prolonged exposure to low doses and low dose rates. It is now known that the possible adverse health effects of such

\footnotetext{
${ }^{*}$ Corresponding author

E-mail address: dhani02@batan.go.id

DOI: https://doi.org/10.17146/aij.2018.851
}

radiation exposure are stochastic effect such as malignant diseases [1]. Until now, several studies have already been conducted to investigate the effects of occupational exposure on hospital staff, people living in high background radiation areas (HBRA), Chernobyl cleanup workers, and radiation workers of nuclear facilities, using conventional cytogenetic analysis [2].

Among various methods available for cytogenetic analysis, the micronucleus (MN) assay in peripheral lymphocytes allows much faster detection of chromosomal damages [3]. Micronucleus assay has many advantages compared 
to other cytogenetic assays since it is rapid, does not require as much specialized expertise, and can be applied to monitor a largepopulation. Micronucleus assay has been used in many biomonitoring studies and is considered as a valuable biomarker of occupational exposure to ionizing radiation in human population [4].

The occurrence of MN is also an important biomarker for DNA repair capacity. It is well known that ionizing radiation can induce double-strand breaks (DSBs) in DNA and that most of DSBs are repaired rapidly and accurately [5]. Genetic variations in DNA repair genes may influence individual DNA repair capacity and risk of developing cancer. Polymorphisms in genes that participate in different DNA repair pathways have been identified, and they are believed to be related to cancer susceptibility and carcinogenesis [6]. The association of singlenucleotide polymorphisms (SNPs) in relevant genes with MN frequencies in peripheral blood lymphocytes (PBLs) represents a valuable tool for attaining a better understanding of the role of SNPs in the pathogenesis of diseases, because the latter is one of the best-validated DNA damage biomarker that is sensitive to a wide range of endogenous, environmental, and lifestyle factors that can harm the genome [7].

Among the many genes involved in DNA repair pathways, the $\mathrm{X}$-ray repair cross complementation group 3 (XRCC3) was selected to analyze in the presents study. The XRCC3 gene is located on the long arm of chromosome 14q32.33. The XRCC3 encodes a member of the $\operatorname{Rec} A / \operatorname{Rad} 51$-related protein family that participates in DSBs repair via the homologous recombination $(\mathrm{HR})$ repair pathway. A transition of cytosine $(\mathrm{C})$ to thymine $(\mathrm{T})(\mathrm{C} \rightarrow \mathrm{T})$ in exon 7 of the $X R C C 3$ gene has been shown to be associated with malignancies. A polymorphism of XRCC3 gene can affect the enzyme's function and its interaction with other proteins involved in DNA damage repair $[8,9]$.

The aim of this study was to evaluate the MN frequencies in the lymphocytes of 30 radiation workers from the Center for Multipurpose Reactor (CMPR), National Nuclear Energy Agency (NNEA) of Indonesia, and 30 control samples. This study also examines the influence of genetic polymorphism XRCC3-T241M on the $\mathrm{MN}$ frequencies in radiation workers and controls. To the best of our knowledge, this is the first study in Indonesia that examines the influence of genetic polymorphism $X R C C 3-\mathrm{T} 241 \mathrm{M}$ on the $\mathrm{MN}$ frequencies in radiation workers.

\section{EXPERIMENTAL METHODS}

\section{Blood sampling and culture}

Blood samples from 30 healthy adult subjects from the Reactor Operational Division (ROD) of CMPR and 30 control samples were collected by venipuncture using heparinized and ethylenediaminetetraacetic acid (EDTA) vacutainer tubes (BD Vacutainer systems). The Reactor Operational Division (ROD) was chosen because based on a 2012 report, it was known that this division had the highest mean of effective dose for whole body exposure for the 2007 to 2011 period [14]. The control samples were the workers from the Center for Technology of Radiation Safety and Metrology (CTRSM), NNEA, who had received a lower effective dose of whole body exposure than the ROD workers. Informed consent was obtained from all donors. A detailed questionnaire was used to obtain information on age and smoking habits. The mean age of CMPR workers was $48.63 \pm 7.44$ years with the range of 29 to 60 years, while the age range of controls was from 32 to 55 years with a mean of $41.1 \pm 8.63$ years, respectively. The detailed characteristics of the samples are presented in Table 1. The ethical clearance was obtained from the health sciences research ethics committee of the Faculty of Health Sciences, Diponegoro University, and Kariadi Hospital, Semarang, Indonesia, number 357/EC/FKRSDK/2016, dated April 1, 2016. The peripheral blood lymphocytes were then cultured according to the MN assay protocol from an International Atomic Energy Agency (IAEA) publication [10]. The scoring criteria were defined based on the Fenech publication from 2007 [11]. One thousand binucleated lymphocytes (BNC) were scored at the magnification of $400 \times$ for each sample.

Table 1. General characteristics of all samples

\begin{tabular}{lccc}
\hline Parameter & \multicolumn{3}{c}{ Number (\%) } \\
\cline { 2 - 4 } & $\begin{array}{c}\text { CMPR } \\
\text { Workers }\end{array}$ & Controls & Total \\
\hline Gender & $28(46.6)$ & $15(25)$ & $43(71.6)$ \\
$\quad$ Male & $2(3.4)$ & $15(25)$ & $17(28.4)$ \\
Female & & & \\
Smoking Habit & $12(20)$ & $28(46.6)$ & $40(66.6)$ \\
$\quad$ Non-Smokers & $18(30)$ & $2(3.4)$ & $20(33.4)$ \\
$\quad$ Smokers & & & \\
\hline
\end{tabular}

\section{Extraction of genomic DNA}

Genomic DNA was purified from whole blood using the QIAamp DNA Blood Midi Kit (Qiagen) according to the manufacturer's instructions. All prepared DNA was then stored at $4{ }^{\circ} \mathrm{C}$ prior to use. 


\section{Genotype analysis by PCR-RFLP}

Isolated DNA was amplified with a polymerase chain reaction (PCR) mixture consisting of PCR Master Mix $10 \mu \mathrm{L}$, Forward Primer $(0.5 \mu \mathrm{M}) 5 \mu \mathrm{L}$, Reverse Primer $(0.5 \mu \mathrm{M}) 5 \mu \mathrm{L}$, and DNA (50 ng) $5 \mu \mathrm{L}$. The primer pairs used were F5'-GGTCGAGTGACAGTCCAAAC-3' and R5'CTACCCGCAGGAGCCGGAGG-3'. The PCR conditions were as follows: a 10 min denaturation step at $95{ }^{\circ} \mathrm{C}$ followed by 30 cycles of $95{ }^{\circ} \mathrm{C}$ for 1 min, $60{ }^{\circ} \mathrm{C}$ for $1 \mathrm{~min}$, and $72{ }^{\circ} \mathrm{C}$ for $1 \mathrm{~min}$, respectively, and a final extension step at $72{ }^{\circ} \mathrm{C}$ for 10 min. Polymorphisms of XRCC3 (Thr241Met) (rs861539) was determined by using the PCR-restriction fragment length polymorphism (PCR-RFLP) method. The PCR amplicons were digested at $37{ }^{\circ} \mathrm{C}$ for $3 \mathrm{~h}$ with discriminating restriction enzyme that recognized and cut either the wild-type or variant sequence site. The restriction enzyme used was NlaIII. The digested PCR products were analyzed on $3 \%$ agarose gels and stained with ethidium bromide. Details of PCR product and restriction fragment sizes are outlined in Table 2.

Table 2. Details of PCR and RFLP fragment sizes of XRCC3 T241M

\begin{tabular}{llll}
\hline PCR & \multicolumn{2}{l}{ Restriction digestion } \\
\hline $\begin{array}{l}\text { Product } \\
\text { Size (bp) }\end{array}$ & Enzyme & Genotype & Fragment sizes (bp) \\
\hline 415 & NlaIII & Thr/Thr & 274,141 \\
\hline & Thr/Met & $274,170,141,104$ \\
\hline & Met/Met & $170,141,104$ \\
\hline
\end{tabular}

\section{Statistical analysis}

The Kolmogorov-Smirnov test was applied to determine the distribution of data. Since the distribution of $\mathrm{MN}$ frequencies was not normal, the Mann-Whitney nonparametric test was used as a statistical test using IBM SPSS 22.0 statistical software. The Hardy-Weinberg equilibrium was tested on genotypic data using Michael H. Court's online calculator for determining whether the observed genotype frequencies are consistent with Hardy-Weinberg equilibrium [12].

\section{RESULTS AND DISCUSSION}

\section{MN frequencies in radiation workers and controls}

The mean $\mathrm{MN}$ frequencies in radiation workers and control group are presented in Table 3. Statistical analysis revealed that the difference of MN frequencies was not significant $(p=0.549)$. This result was in agreement with another study that found aninsignificant difference of MN frequencies between radiation workers and control samples [3]. In contrast, a study in Tunisia revealed that there was a significant increase of the $\mathrm{MN}$ frequencies in the lymphocytes of the hospital radiation workers compared to the control group [13]. The difference in MN assay technique between this study and the study in Tunisia may have affected the difference in results on MN frequencies. The study in Tunisia used a MN centromere assay that combined MN assay with pan-centromeric probe to detect MNs derived from acentric chromosome fragments. It is well known that most of the radiation-induced MN originate primarily from acentric fragments while spontaneous $\mathrm{MN}$ contains especially whole chromosomes. There is now some evidence that centromere identification in $\mathrm{MN}$ can increase the sensitivity of the CBMN assay in the low-dose range $[10,13]$. Further studies using $\mathrm{MN}$ assay in combination with pan-centromeric probe should be conducted to confirm this study results. Other SNPs in the XRCC3 gene also should be examined to determine whether the SNPs can contribute to the increase of $\mathrm{MN}$ frequencies.

Another factor that may contribute to the insignificant difference of MN frequencies between radiation workers and control samples was the accumulated dose of radiation. Based on the 2012 report, the mean of effective dose for whole body exposure or $H p(10)$ from 2007 to 2011 in Reactor Operational Division workers of CMPR was $3.27 \mathrm{mSv}$ [14]. This value was much lower than the results ofanother study that found a significant difference in dicentric, ring, and fragment chromosomes when the accumulated doses value was more than $300 \mathrm{mSv}$ [1]. Another study that evaluated the radiation workers in hospital also reached a result similar with our findings. Ropolo et al. did not find a significant difference in $\mathrm{MN}$ frequencies between the group that had an accumulated dose of less than $2.5 \mathrm{mSv}$, those that had an accumulated dose between $2.5 \mathrm{mSv}$ and $10 \mathrm{mSv}$, and those that had more than $10 \mathrm{mSv}$ [3].

It can also be seen that the mean MN frequency in radiation workers was lower than in the control group. It is possible that aradioadaptive response phenomenon developed in radiation workers. The radioadaptive response (RAR) defined as the biological response where an exposure of low dose radiation (priming dose) to organism induces protection mechanisms against the detrimental effects of a subsequent larger radiation exposure (challenging dose) [15,16]. Assessment of individual radiosensitivity in the ROD workers of CMPR should be conducted in a further investigation to confirm the RAR phenomenon. 
Table 3. MN frequencies in radiation workers and control groups

\begin{tabular}{ccc}
\hline Group & Mean MN Frequencies & $p$ value \\
\hline Radiation workers & 0.019 & 0.549 \\
\hline Control & 0.021 & (NS) \\
\hline NS: Not Significant & &
\end{tabular}

\section{Gender, age, and smoking habit effects in MN frequencies}

Our study revealed that there were insignificants difference of $\mathrm{MN}$ frequencies in respect to gender, age, and smoking status (Table 4). Interestingly, MN frequencies in females were higher compared to in males, even though the difference was not significant. Researchers suspect that the higher $\mathrm{MN}$ frequencies in females correspond to the greater tendency of the inactive $\mathrm{X}$-chromosome to be lost as an $\mathrm{MN}$ relative to other chromosomes, and to the fact that females have two copies of the chromosome compared to only one in males [17-19]. A study by Antunes et al. showed similar finding to our study. They found the insignificantly higher $\mathrm{MN}$ frequencies in females compared to males [20].

The increase of MN with age is due to a combination of several factors, namely: (i) the cumulative effect of acquired mutations in genes involved in DNA repair; and (ii) the numerical and structural aberrations in chromosomes caused by exposure to endogenous genotoxins, inadequate nutrition, and exposure to environmental or occupational genotoxins, as well as a wide range of unhealthy lifestyle factors [17,21]. Here, in this study, we did not find an increase of MN frequency with age. Smoking status in this study also did not affect the $\mathrm{MN}$ frequencies in all samples.

Table 4. MN frequencies in respect to gender, age and smoking status in all samples

\begin{tabular}{|c|c|c|}
\hline Variables & Mean MN Frequencies & $p$ value \\
\hline Gender & & \multirow{3}{*}{$\begin{array}{c}0.3 \\
\text { (NS) }\end{array}$} \\
\hline Male & 0.018 & \\
\hline Female & 0.024 & \\
\hline Age & & \multirow{3}{*}{$\begin{array}{c}0.828 \\
\text { (NS) }\end{array}$} \\
\hline$>50$ & 0.020 & \\
\hline$<=50$ & 0.020 & \\
\hline Smoking Status & & \multirow{3}{*}{$\begin{array}{c}0.753 \\
\text { (NS) }\end{array}$} \\
\hline Yes & 0.0205 & \\
\hline No & 0.0204 & \\
\hline
\end{tabular}

NS: Not Significant

\section{Distribution of T241M XRCC3 polymorphism and itsassociation with MN numbers}

Distribution of XRCC3 genotypes and variant allele frequencies in radiation workers and controls are presented in Table 5. There are no statistically significant differences in the genotype distributions between radiation workers and controls $(p=0.1607)$. The genotype distributions in all groups were in Hardy-Weinbergequilibrium. Allele frequencies were also in agreement with previous publication [22].

Table 5. Distribution of $X R C C 3$ genotypes in radiation workers and the controls

\begin{tabular}{lllll}
\hline Gene & Genotype & $\begin{array}{l}\text { Radiation } \\
\text { Workers, } \\
\mathrm{n}(\%)\end{array}$ & $\begin{array}{l}\text { Controls, } \\
\mathrm{n}(\%)\end{array}$ & $\begin{array}{l}\text { Total, } \\
\mathrm{n}(\%)\end{array}$ \\
\hline \multirow{2}{*}{ XRCC3 } & Thr/Thr & $28(93.3)$ & $29(96.6)$ & $57(95)$ \\
\cline { 2 - 5 } & Thr/Met & $2(6.6)$ & $1(3.3)$ & $3(5)$ \\
\cline { 2 - 5 } & Met/Met & 0 & 0 & 0 \\
\hline Allele & Thr & 0.50 & 0.48 & 0.98 \\
\cline { 2 - 5 } frequency & Met & 0.009 & 0.011 & 0.02 \\
\hline
\end{tabular}

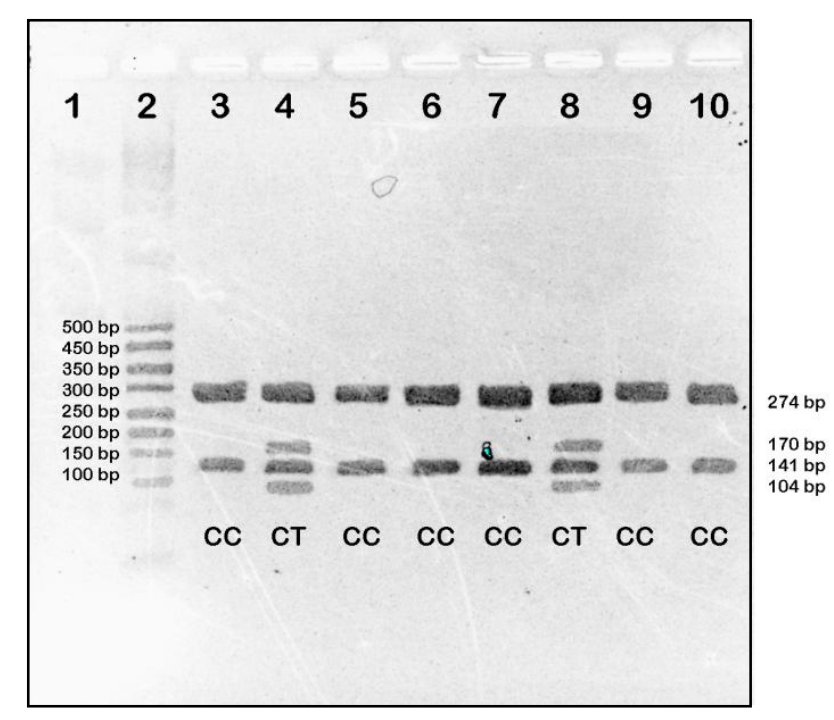

Fig. 1. PCR-RFLP analysis of XRCC3 Thr241Met polymorphism. Lane 1: blank, lane 2 :molecular marker $50 \mathrm{bp}$ DNA ladder, lanes 4 and 8 : heterozygous Thr/Met variant genotypes, lane 3,5,6,7,9,10:homozygous wild-typeThr/ Thr genotype.

As can be seen in Table 5 and Fig. 1, only two samples among radiation workers, and one among controls, have Thr/Met genotype. From all samples that have Thr/Met genotype, only one person in controls has a higher MN number than the background frequency $(0-40)$ which was 50 in 1000 BNC. The other two have MN numbers below 40 in 1000 BNC. Based on this finding, it cannot be concluded whether $\mathrm{T}$ allele can increase the $\mathrm{MN}$ frequencies. Another study by Milić et al. found the significantly higher of $\mathrm{MN}$ frequencies in individuals that have wild-type homozygous polymorphic SNP (Thr/Thr) compared to those with the heterozygous polymorphic SNP [23]. 
Differences in samples' ethnicity could be the reason why in this study the association of $\mathrm{MN}$ and T241M XRCC3 was not found. Another factor that possibly contributed is the samples used were too homogeneous, since most of the samples especially in radiation workers were Javanese and in the same age range. It is also possible that the T241M in $X R C C 3$ was not a specific subtype of polymorphism correlatingto $\mathrm{MN}$ frequencies. Other polymorphism subtypes in XRCC3 such as A4541G (rs1799794) and A17893G (rs1799796) are probably more specific polymorphisms that correlate with $\mathrm{MN}$ frequencies induced by low radiation dose exposure. A recent meta-analysis revealed that the rs 1799794 polymorphism may have a protective effect against the late adverse effects of radiotherapy [24]. It is also possible that rs1799794 has a protective effect against chronic low radiation dose exposure, since in our study the $\mathrm{MN}$ frequencies in radiation workers was lower than in controls. A further study on rs1799794 and rs1799796 polymorphism subtypes and its correlation with $\mathrm{MN}$ frequencies should be conducted.

\section{CONCLUSION}

The MN frequencies in CMPR worker was not significantly different from control samples. Age, gender, and smoking habit factors did not correlate to $\mathrm{MN}$ frequencies in all samples. The association between T241M XRCC 3 and MN frequencies was also not found in this study. It can be concluded that the occupational exposure to radiation received by CMPR workers did not induce a significant increase of chromosomal instability in their lymphocytes.

\section{ACKNOWLEDGMENT}

The authors would like to thank all staff members of the Center for Multipurpose Reactor, National Nuclear Energy Agency of Indonesia, for participating in this study. They would like to give their deepest thanks for the Head of Center for Multipurpose Reactor, Ir. Bambang Herutomo, the Head of Reactor Operational Division, Ir. Eko Yusi Yulianto, and the Head of Operational and Work Safety Division, Drs. Slamet Suprianto.

\section{REFERENCES}

1. R. Hristova, V. Hadjidekova, M. Grigorova et al., J. Radiat. Res. 54 (2013) 832. DOI: 10.1093/jrr/rrt018.

2. L. Han, F.-L. Zhao, Q.-F. Sun et al., Mutat. Res. Genet. Toxicol. Environ. Mutagen. 771
(2014) 1.

DOI: 10.1016/j.mrgentox.2014.06.003.

3. M. Ropolo, C. Balia, P. Roggieri et al., Mutat. Res. - Genet. Toxicol. Environ. Mutagen. 747 (2012) 7.

DOI: 10.1016/j.mrgentox.2012.02.014.

4. T.H. Ryu, J. Kim, and J.K. Kim, J. Ecol. Environ. 37 (2014) 195.

DOI: 10.5141/ecoenv.2014.023.

5. A. Saberi, E. Salari and S.M. Latifi, Mutat. Res. 750 (2013) 92.

DOI: 10.1016/j.mrgentox.2012.10.001.

6. H. Doukali, G. Ben Salah, B. Ben Rhouma et al., Int. J. Radiat. Biol. 93 (2017) 1283.

DOI: 10.1080/09553002.2017.1377361.

7. M. Sinitsky, A. Larionov, M. Asanov et al., Int. J. Radiat. Biol. 91 (2015) 486.

DOI: 10.3109/09553002.2015.1012306.

8. C. Bănescu, M. Tilinca, E.L. Benedek et al., Gene 526 (2013) 478.

DOI: 10.1016/j.gene.2013.05.054.

9. F. Chai, Y. Liang, L. Chen et al., Med. Sci. Monit. 21 (2015) 3231.

DOI: 10.12659/MSM.894637.

10. Anonymous, Cytogenetic Dosimetry: Applications in Preparedness for and Response to Radiation Emergencies, International Atomic Energy Agency, Austria (2011).

11. M. Fenech, Nat. Protoc. 2 (2007) 1084. DOI: $10.1038 /$ nprot.2007.77.

12. M.H. Court, Michael H. Court's (2005-2008) Online Calculator, Tuft University Website http://www.tufts.edu/ mcourt01/Documents/C ourt\%201ab\%20-\%20HW\%20calculator.xls.

Retrieved in March (2016)

13. S. Bouraoui, S. Mougou, A. Drira et al., Int. J. Occup. Med. Environ. Health 26 (2013) 144. DOI: 10.2478/s13382-013-0084-4.

14. Sunarningsih, Mashudi, A. Lilik, Yosep, Pros. Semin. Nas. Teknol. dan Apl. Reakt. Nukl., Pusat Reaktor Serba Guna, Badan Tenaga Nuklir Nasional, Serpong (2012) 51.

15. D. Wodarz, R. Sorace and N.L. Komarova, PlosComput. Biol. 10 (2014) 1.

DOI: 10.1371/journal.pcbi.1003513.

16. M. Kadhim, S. Salomaa, E. Wright et al., Mutat. Res. 752 (2013) 84.

DOI: 10.1016/j.mrrev.2012.12.001. 
17. E. Rastkhah, F. Zakeri, M. Ghoranneviss et al., Radiat. Environ. Biophys. 55 (2016) 41. DOI: 10.1007/s00411-015-0624-3.

18. H. Nefic, I. Handzic, Mutat. Res. 753 (2013) 1 DOI: 10.1016/j.mrgentox.2013.03.001.

19. J. Pajic, B. Rakic, D. Jovicic et al., Mutat. Res. 773 (2014) 23.

DOI:10.1016/j.mrgentox.2014.07.009.

20. A.C. Antunes, V. Martins, J. Cardoso et al., Mutat. Res. - Genet. Toxicol. Environ. Mutagen. 760 (2014) 17.

DOI: 10.1016/j.mrgentox.2013.09.012.
21. J. Pajic, B. Rakic, B. Rovcanin et al., Radiat. Environ. Biophys. 54 (2015) 317. DOI: $10.1007 / \mathrm{s} 00411-015-0596-3$.

22. J.Y. Huang, J.F. Yang, Q. Qu et al., Genet. Mol. Res. 14 (2015) 10569.

DOI: 10.4238/2015.September.8.18.

23. M. Milić, R. Rozgaj, V. Kašuba et al., ArhHig Rada Toksikol 66 (2015) 109.

DOI: 10.1515/aiht-2015-66-2655.

24. Y.-Z. Song, F.-J. Han, M. Liu et al., PLoS One $10(2015) 1$.

DOI: 10.1371/journal.pone.0130388. 